\title{
Text without Context: \\ On Bloom's MisReading of J
}

\author{
Carol Meyers
}

On the second day of the Gulf War, the chief science editor of the New York Times called. He wanted to know the exact location of the Garden of Eden for a piece he was preparing on the air war in Iraq and its affect on antiquities sites. I was impressed that he was checking out his story with someone who is supposed to know something about the Bible and about archaeological remains. And I was even more impressed when, after a forty-five-minute conversation about the imagery of paradisiacal gardens and the trans-historical complexities of early biblical traditions, he scratched the story. A consummate master of his own profession, he recognized that his interest in Eden meant stepping into the difficult terrain of another discipline; he wisely backed away.

Not so Rosenberg and Bloom. They have been unwilling to recognize that the Bible is not user friendly. Though they would distance themselves from believers who hold that scripture is the revealed word of God, they share with the faithful the notion that the Bible is accessible to all who would leaf through its pages. Because biblical allusions, characters, and language are so much a part of contemporary western culture, it seems that the holy text itself is of this time. Well, in some ways it is. Yet it is also radically distant and other, a product of a time and a place so removed from our own world that we would suffer severe culture shock were we to be plunked down in a mountain village in Palestine of three millennia ago.

Perhaps Bloom's greatest contribution to naive and even sophisticated Bible readers who are swept away by his innovative readings of the first great masterpiece of western literature is his insistence that the literary power and originality of one of the earliest narrative strands of the Bible has been occluded by subsequent layers of tradition. These layers include the very material that surrounds it - the other narrative strands that supplement it, amplify it, and in so doing presumably violate some earlier authorial integrity. The J narrative comes to us with its edges blurred and its own story incomplete. If it is a reality at all, and not a theoretical fig- 
ment of the imagination of generations of Bible scholars and of the audacious analysis of Bloom, its original form can never be recovered, unless some miracle of archaeology produce an Urtext of J's full creation.

Those early canonical layerings that obscure J's art are just the beginning of the historic misreadings to which the $\mathrm{J}$ source and the other literary monuments of the Pentateuch have been subjected. For millennia the Bible has been the provenance of believers and their interpretations. And for more than a century it has been territory for countless scholarly treks by both academics and clerics. The artful originality of the Bible and its foundational amalgam of radical messages giving life to a tiny community precariously perched amidst giants have been swallowed up and disguised by post-biblical critics who have been too often guided by their own contexts than by the very texts that start them on their journeys of belief and of scholarship.

Yes indeed the Bible has been misread. And we all suffer the consequences of the misreadings; for politicians and theologians alike use their versions of scriptural passages to justify policies and theologies that are all too unbiblical. Both those who uphold the privileged place of scripture and those who would distance themselves from it are trapped by the distortions of centuries of misreadings. If Bloom can rescue us from those mistaken visions of the biblical truths, then he would be as liberating of the mind as Yahweh was liberating of the ancient community of Israelites. Still, Bloom is hardly the first to signal the misapprehension of scripture by the many layers of commentary; some extremely cogent critiques of biblical scholarship (such as Robert Oden's The Bible without Theology [San Francisco: Harper and Row, 1987]) have unmasked, for example, the dark power of nineteenth- and twentieth-century German Christianity in its shaping of contemporary biblical studies.

But the authors of those critiques do not have the audience that Bloom enjoys. While they may influence their fellow academicians, who may ultimately, over many decades, reshape general cultural attitudes, that process is painfully slow, indirect, and ponderous. And perhaps it will not ever happen. The wider world of Bible readers needs a jolt to its somnolent accession to traditional readings. The Book of J provides such a jolt. It shocks us into questioning what has been beyond question. But there the value of Bloom's courageous proclamation that layers of tradition have occluded 
our vision of the precious core (which, ironically, the blurring processes of tradition have sought to preserve and sustain) unfortunately ends.

Bloom's work itself, as he of course admits, becomes the latest in a millennia-long series of misreadings. He has stepped into the unfamiliar world of an ancient Semitic text, where he has deliberately and eloquently used the critical tools honed on his eminent work on masterpieces of English literature. In so doing he has superimposed a post-biblical, nonHebraic literary mind-set upon the otherness of the Hebraic world. Such an exercise is not impossible. But it is lethal to the social and artistic inventions of the underlying terrain to ignore the complex features of that landscape. In virtually ignoring the world of $\mathrm{J}$, as it existed beyond the walls of her palatial Jerusalem villa restored by Bloom's cunning-admittedly without a shred of reliable evidence-he, no less than the scholars and sages he berates, has failed his readers. Bloom has given us a text without a context. He thereby deludes us, and he also deprives us of what $\mathrm{J}$ meant for the earthly and heavenly contours of ancient Israel.

Biblical scholarship strives to recover context, so that the story of $J$ and of all other anonymous biblical authors, along with the few with names, can be heard as they were meant to be heard. Bloom has given lip service to that scholarship, though strangely he has relied most often on precisely those German Protestant scholars whose heavily theological approaches he would most eschew. But he cannot possibly have acquired, in however many months or years he devoted to preparing The Book of $J$, the depth and familiarity patiently acquired by those who have dedicated their graduate studies and professional careers to biblical studies. He has not recovered the context of J's materials, and so he has made assertions that undermine much of his argument about J's God, about J's understanding of humanity, and about J's gender. Let us look at an example of each of these three facets of Bloom's work.

Who is this Yahweh that is the protagonist of J's work and who is clearly of great concern for Bloom's quest? Bloom shakes Yahweh loose from rabbinic and patristic theologies. So far so good. But what do we see instead? What Bloom does with the first scene makes us question what he does with all subsequent ones. Our first glimpse of J's Yahweh is at the moment of creation, that sublime, earth-centered, human-centered moment of beginnings. But the image of Yahweh Bloom gives us is that 
of a child playing in the mud, randomly making objects out of the wet clay. Can the beginnings of human life be that devoid of design in J's perception?

Bloom has drawn a contrast between the Yahweh of Genesis 2 and something he has read about deity-as-potter in the ancient Near East. That metaphor indeed exists; but it does not fit the scene of Genesis 2 as Bloom correctly points out. Potters at their wheels made utilitarian vessels. Yahweh makes a human being. But rather than engaging in child's play, Yahweh thereby stands in the tradition of coroplasts, whose very craft may have originated in Bible lands and whose artistic accomplishments stand out among the plastic arts of the ancient east Mediterranean world. Yahweh formed the clay according to the coroplast's mode, with artful intent. The vitality of human life thereby is an extension of divine creative purpose rather than a sign of impishness. This image is a far cry from the Yahweh depicted by Bloom at the first and that thus underlies all that follows. If we cannot trust what Bloom gives us at the first, how can we take seriously all that follows?

Yahweh is to be known by deeds, and the dynamism of Yahweh's interaction with the Israelite forebears speaks volumes about the essence of this god. But we miss the startling and momentous implications of this god by not seeing how this bestower of the Blessing, this one who saves oppressed peoples, was a new thing on earth. J's originality in a literary sense bespeaks the radical originality of the god who, intertwined with early individuals of Hebrew history, is the power that generates the text. If J did not see such an extraordinary Yahweh, she would not, could not, have devised such an extraordinarily engaging portrayal of cosmic, human, and Hebrew beginnings.

J's work needs to be read as a Beginnings tale, set over and against the cosmogonies of other ancient peoples, more than it needs to be read through the eyes of Franz Kafka and Thomas Mann, more than it needs to be seen against the achievements of Shakespeare and Milton. The problem is that the sort of context that will illuminate J's contribution on an ideological as well as literary level is not so accessible as is Mann or Milton. One needs to know long-dead and difficult writing systems and literatures, apparently quite beyond the reach of a mature critic of western literature. 
Bloom's somewhat sarcastic treatment of the scholarship on J's anthropomorphic rendering of Yahweh is similarly founded on assumptions that may not be valid for an ancient Semitic text. We are told that J's Yahweh is the "uncanniest of all Western metaphors" (15), but we are left woefully ignorant of the function of metaphors in Semitic, pre-western constructions. To be sure, western modes of thought emerge from Near Eastern antiquity. But they have been significantly altered by transmission through the Greco-Roman world. And the alterity of Semitic modes of perceiving and expressing reality is critical to comprehending the biblical portrayals of Yahweh. The imagery of Yahweh's human-like behavior is not a literal delineation nor an allegorical rendering. It is a highly poetic way of communicating abstract thought. Once Greek philosophy was superimposed on the Hebraic tradition, the subtle genius of such expression began to appear irrational and fanciful. The special qualities of mythopoetic thought devoted to the pondering of cosmic and community beginnings are lost to us if we look at J's work only in relation to the pinnacles of western literature from the Greeks onward.

Next, what about J's view of humanity? I take only one example, one to which I have given considerable attention in my own work. Like Bloom, I am interested in seeing the text without the accretions, and I have worked especially hard to see the Eden of Gen. 2:46-3:24 and to understand Eve's role in J's creation. But, looking at Rosenberg's chapters 1-10 and Bloom's comments on them, I see something that diverges from what the Hebrew proclaims. This is especially true for a verse that has profoundly influenced western attitudes toward women: the one that is believed by many to be Yahweh's mandate for women to experience pain in childbirth.

Rosenberg has mutilated this text (Book of $J$ 8; Gen. 3:16), giving us words and concepts of which the Hebrew is devoid - no bellies or male eagerness there. But especially no "pain." The Hebrew word so rendered is another marvelous pun -it is the same Hebrew word as that denoting the man's fate, his hard and unremitting "toil" in the unyielding highlands of his future homeland. Even an aristocratic J would have seen that a woman's lot involved hard work, as did that of a man, in addition to many pregnancies. How else could Israelites survive in the marginal environment of the Palestinian hills? But neither Bloom nor Rosenberg have worked to see that context. And instead they perpetuate a mentality under 
which women have suffered for millennia. J's Yahweh did not give women pain as they created their future; Yahweh gave them a life of hard work that even a noblewoman in Jerusalem could memorialize in her use of this poetic fragment portraying the human condition.

Now, how can we respond to what Bloom understands as J's gender? He prods us with this notion; and he prizes its outrageousness. But the audacity of crediting the masterpiece of J to a woman's hand is merely a reflection of his acceptance of the very post-biblical layering to which he objects. That is, only an androcentric and patriarchalizing reading of $\mathrm{J}$ - which is precisely what tradition has provided - could lead us to believe that the incomparability of scripture could not have been generated in part by a woman's spirit. The proposition that such was indeed the case is viewed as shocking only if one's angle of vision is so patriarchally slanted that a female cannot be unremarkably seen as the author of such a sublime tale.

It is an open question as to whether women were deemed inferior, secondary, and otherwise incapable of high art in Israelite antiquity. Most likely such rigid stances are largely post-biblical. Bloom is peering at Israelite society through Miltonian hierarchical lenses. He has cast off other accretions but not this one.

The fact that J's women are so sympathetically drawn, that they appear resolute and heroic in achieving the continuity of the Blessing, may not be a result of a female's predilection but rather a reflection of a reality. In the formative struggles of the Israelites to root themselves in Canaan, to combat the forces of death that beset them on all sides in the inhospitable hilltop villages of their homeland, female tenacity, diplomacy, and fecundity did much to sustain them. Whether J was a woman or not, the family story that $\mathrm{J}$ was moved to tell demanded a heightened portrayal of the women whose vitality of spirit and body gave life to the story, to the people, and to the god symbolizing the successful urge to life.

By making the suggestion that $\mathrm{J}$ was a woman seem outrageous, the very generosity of female wills and wiles depicted by $\mathrm{J}$ is mocked. If that is what female authorship of J entails, we would all be better served by positing male imagination as the generative force behind this or any other of the truly great biblical writings. But if we can shed all misreadings, including those of Bloom and Rosenberg, then perhaps the unbounded creativity of female contributions to literature and life can be recognized. 